\title{
On General Concept of So-called Glycoproteins.
}

(A lecture presented at the Japanese Biochemical Society in Osaka, October 29-31, 1943, with partial correction.)

By

Hajime Masamune.

(正 宗 一)

(From the Medico-Chemical Institute, Tohoku

Imperial University, Sendai.)

(Received for publication, April 10, 1945)

The results hitherto obtained by my co-workers and me may be summarized as below and a conclusion drawn therefrom was that, of so-called glycoproteins, those which involve an itin or an itinsulfuric acid or alikes such as heparin are real glycoproteins in the sense of a kind of conjugated protein and the others should be classed among simple proteins.

1. Components of the Carbohydrates in

$$
\text { So-called Glycoproteins. }
$$

Methods for determination of various sugars (amino sugars, ${ }^{1 / 2)}$ hexoses ${ }^{3)}$ and hexuronic acids ${ }^{456) 71}$ ) and others ${ }^{8}$ in so-called glycoproteins were devised or improved, and scission of these proteins (by means of an alkali or enzyme), separation of the polysaccharides with following purification, analysis, and identification of sugar constituents were carried out. According to the results, this kind of protein is not confined to involve only one kind of polysaccharide in the molecule, but some possess two or even three. In the make-up of these polysaccharides, as is illustrated in Table I, take part

glucuronic and galacturonic ${ }^{35)}$ acid, mannose, galactose and

a methylpentose (probably rhodeose) ${ }^{19)}$

as non-nitrogenous sugars, and, as amino sugars,

chitosamine and chondrosamine. ${ }^{20}$

To enumerate further characteristic features:-

(a) Hexosamine- $\mathrm{N}$ is mostly* combined with acetyl. In some of the polysaccharides even all of hexosamine molecules hold a pyrrolidine ring besides (Table II). ${ }^{36 / 37)}$

(b) They are each made up of one kind or two of hexosamine and 
TABLE I.

Carbohydrates in Glycidamins and Glycoproteins.

\begin{tabular}{|c|}
\hline Protein \\
\hline Mucin from snail foot ${ }^{9 /}$ \\
\hline Urinomucoid ${ }^{10)}$ \\
\hline $\begin{array}{l}\text { Mucoa-mucoid from } 4 \text { th } \\
\text { stomach of bull'11 }\end{array}$ \\
\hline Cornea mucoid ${ }^{12)}$ \\
\hline Tendomucoid $\alpha^{13\}}$ \\
\hline Ovomucoid(114)17) \\
\hline Vitellomucoid ${ }^{15) 16)}$ \\
\hline Seromucoid ${ }^{16) 17(18)}$ \\
\hline Pseudomucin ${ }^{181}$ \\
\hline $\begin{array}{l}\text { Mucinogen from covering } \\
\text { of toad eggs }\end{array}$ \\
\hline Funis mucin $22123 / 241$ \\
\hline $\begin{array}{l}\text { Mucin from vitreus } \\
\text { humor }^{25)}\end{array}$ \\
\hline Saliva mucoid ${ }^{26) 271}$ \\
\hline Saliva mucin ${ }^{27 / 28 / 29 / 301}$ \\
\hline Sclera mucoid $\beta^{311}$ \\
\hline Sclera mucoid $\alpha^{311}$ \\
\hline Chondromucoid ${ }^{24 / 32 / 33 / 3}$ \\
\hline Osseomucoid ${ }^{23 / 34 !}$ \\
\hline Tendomucoid $\beta^{13}$ \\
\hline $\begin{array}{l}\text { Mucus-mucinogen of } \\
\text { snail }^{9 / 35}\end{array}$ \\
\hline
\end{tabular}

\begin{tabular}{ccc}
\multicolumn{3}{c}{ Carbohydrate } \\
\hline Acetylchitosamine-galactose $(1: 1)$ & complex \\
" " & $(1)$ & " \\
" & $(2: 3)$ & $\prime \prime$
\end{tabular}

Acetylchitosamine-galactose-sulfuric acid $(1: 1: 1)$ complex
"
" "
$(2: 2: 1)$ complex

Acetylchitosamine-mannose $(5: 4)$ complex

$$
\text { " } \quad(10: 11) "
$$

Acetylchitosamine-galactose-mannose (4:3:3) camplex Acetylchitosamine-galactose- a methylpentose ( ) complex

Acetylchondrosamine- " $\quad$ - ? $(2: 3: ?)$ " Mucoitin

Third carbohydrate of saliva mucin (Tanabe); Mucoitin chitosamine-mannose (1:2) complex " "); " ; AcetylAcetylchitosamine-mannose complex; Chondroitinsulfuric acid.

Two acetylchitosamine-mannose-sulfuric acid complexes or one acetylchitosamine-mannose-sulfuric acid complex and one acetylchitosamine-mannose complex; Chondroitinsulfuric acid

Acetylchitosamine-galactose-sulfuric acid $(2: 2: 1)$ complex; Chondroitinsulfuric acid.

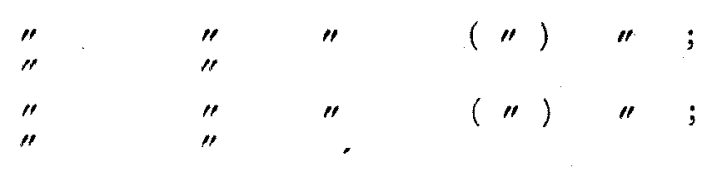

Acetylchitosamine-galactose (1:1) complex; Limacoitinsulfuric acid

one kind or two of non-amino sugar. Some carbohydrates (f. $i$, that in paramucin ${ }^{381}$ ) contain glucosamine as well as chondrosamine. Those, in which two kinds of non-amino sugar are present, are found in seromucoid, pseudomucin and mucinogen from the outer covering of toad eggs.

(c) Among those that are constituted of the same kinds of sugar, first, some are esterified by sulfuric acid and some are not (comp. the polysaccharide of cornea mucoid with that of the mucin from snail foot); second, molecular ratios between the sugar-components are not definite (see the relation between polysaccharides of ovo-and vitello-mucoid); and third, atoms of the hexosamine nitrogen are not always in a single form in one polysaccharide, for instance, in the carbohy- 
drate of mucin from snail foot all of them link merely with an acetyl rest (open type), while, in the corresponding carbohydrate of urinomucoid some further take part in ring formation (closed type). (Table II).

T A B LE II.

Classification of the Carbohydrates of Glycidamins and Glycoprotins according to the Form of Hexosamine-Nitrogen.

(From Osaki and Turumi. ${ }^{37}$ )

I. The carbohydrates in which all atoms of hexosamine-nitrogen are of open type:

Mucoitin

Chondroitinsulfuric acid

Limacoitinsulfuric acid

Acetylchitosamine-galactose complex in the mucus mucinogen of snail

The polysaccharide in the mucin from snail foot

" in ovomucoid

1I. The carbohydrates in which some atoms of hexosamine-nitrogen are of open type and some of closed type:

Third carbohydrate (Tanabe) of saliva mucin (the carbohydrate in saliva mucoidglycidamin)

The polysaccharide in seromucoid

$\begin{array}{ll}\prime \prime & \text { in urinomucoid } \\ \prime \prime & \text { in the mucosa-mucoid from the 4th stomach of bull } \\ \prime \prime & \text { in tendomucoid } \\ \text { in the mucinogen from the covering of toad eggs }\end{array}$

Blood group A substance from the mucus of hog stomach .

Acetylchitosamine-galactose-sulfuric acid complex in chondromucoid
"
',
"
" in osseomucoid

III. The carbohydrates in which all atoms of hexosamine- $\mathcal{N}$ partake in ring formation (closed type):

The polysaccharide in vitellomucoid

In short, various polysaccharides are found in various so-called glycoproteins.

Incidentally, it should be noted that mucoitin does not appear to exist as a monosulfate in the animal body. The presence of mucoitinsulfuric acid (Levene) was recently asserted or alluded in cornea mucoid (Meyer), gastric mucosa (Meyer), " dissolved mucin "” of gartric juice (Komarov), and mucus mucinogen of snail (Suzuki), but these substances have been realized by us to have an acetylchitosamine-galactose-sulfuric acid-compound, ${ }^{12)}$ mucoitin itself, ${ }^{39)}$ an acetlychitosamine-galactose-sulfuric acidcompound (a compound made up of similar components as the one in cornea mucoid $)^{49)}$ and a polysaccharide composed of acetylchitosamine and galacturonic and sulfuric acid $\left([\alpha]_{D}^{19} \text { of the acid sodium salt, } 98.0^{\circ}\right)^{35}$ ) respectively. The last carbohydrate was designated "limacoitinsulfuric acid." 
2. Nature of Glycoprotein-Proteins.

Analysis of umbilical and submaxillary mucin and ovo-, osseo-, chondroand submaxillary mucoid showed that, except in submaxillary mucin $\dagger$ and mucoid, total base- $\mathrm{N}$ (nitrogen of hexone bases and cystin) and total dicarboxylic $\mathrm{N}$, both as calculated in per cent of the protein moiety, amount similar to the corresponding nitrogen in most acid simple proteins. ${ }^{40141}$ In the second place, the number of molecules of lysine exceeded that of arginine in all the substances above excepting the saliva mucoid, resembling the quantitative relation of these amino acids in animal albumins and globulins. And in the third, osseo- and chondro-mucoid and funis mucin were rich in both tryptophane and tyrosine, and ovomucoid was likely rich in tyrosine, though poor in typtophane, whereas in the saliva mucoid both these amino acids were scarce as in scleroproteins. ${ }^{42}$ The quantitative figures thus suggested that most of so-called glycoproteins are formed by participation either of an albumin or of a globulin, exclusive of those in mucus. Therefore we further examined their cleavability by proteinases (pepsin and trypsin) to decide the nature of the amino acid groupings more precisely.

In this experiment, ${ }^{43)}$ the above mucins and mucoids were all digested, but to different degrees as arranged below, the last one being least digestible.

By pepsin:

Osseomucoid $>\left(\begin{array}{l}\text { Chondromucoid } \\ \text { Submax. mucin } \\ \text { Umbilical mucin }\end{array}\right)>$ Ovomucoid $>$ Submax. mucoid.

By trypsin:

Chondromucoid

$\left(\begin{array}{l}\text { Submax. mucin } \\ \text { Umbilical mucin }\end{array}\right)>$ Osseomucoid $>$ Ovomucoid $>$ Submax. mucoid.

The hydrolysableness by both of the enzymes distinguished them from animal albumins, egg- and blood-albumin, that were not attacked by trypsin and also from scleroproteins, collagen and elastin, which were resistant to pepsin besides, although ovomucoid and in particular submaxillary mucoid exhibited only faint digestibility in harmony with their analytical deviation.

From what have been noted in this section, we incline to assume that animal globulins generally take part in the make-up of so-called glycoproteins other than those secreted from mucous cells and those in these cells.

3. The Type of Combination between the Carbohydrate and the Protein Moiety.

When agitated with water at different $\mathrm{pH}$ 's of and below 4.4, the insoluble residues of chondromucoid and umbilical mucin ${ }^{44)}$ (prepared by precipitation from the tissue extracts at a $\mathrm{pH}$ of about 2) contained 
various quantities of chondroitinsulfuric acid and of mucoitin respectively, the content increasing with the decrease of the $\mathrm{pH}$ as low as about 2.0 (Fig. 1). At pH's below 2.0 remained the value of chondroitinsulfuric acid constant. Umbilical mucin dissolved entirely in water at $\mathrm{pH}$ 's less than 1.8.

Fig. 1.

Equivalent ratios of associated mucoitin and chondroitinsulfuric acid to total free basic protein-N at different $\mathrm{pH}$ 's.

(From Masamune and Yasuoka ${ }^{44}$ )

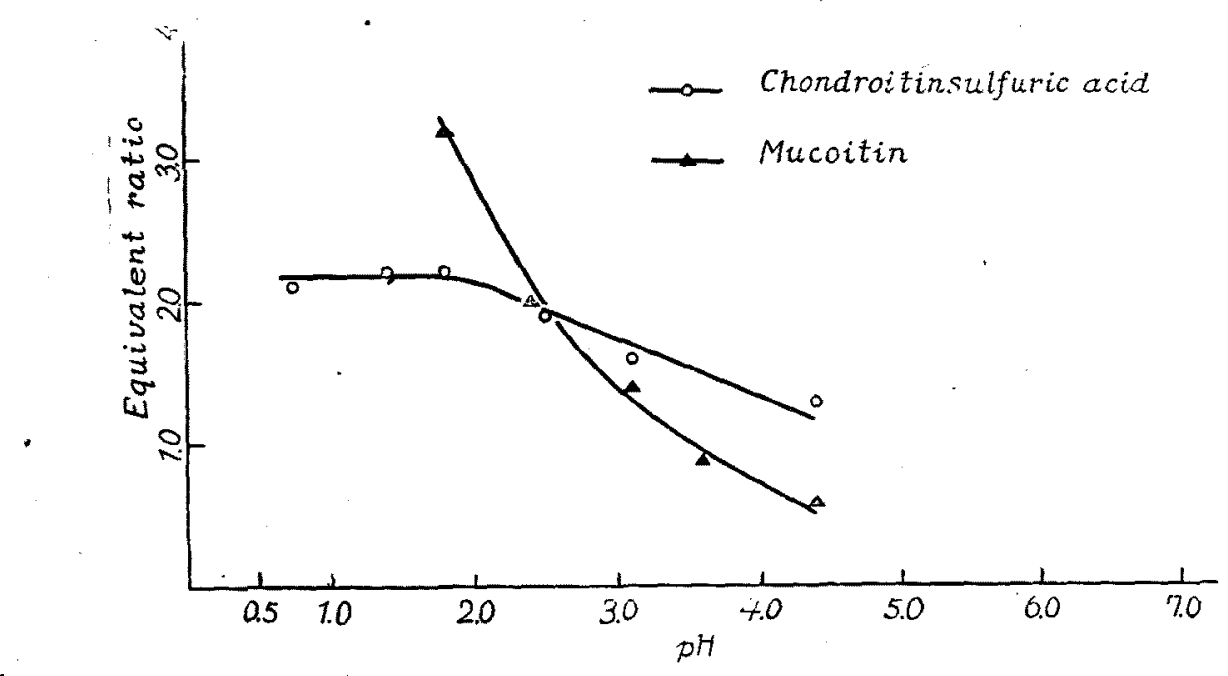

Moreover all chondroitinsulfuric acid could be removed from the mother mucoid at $\mathrm{pH} 7$ by the aid of a chloroform-amylalcohol mixture, but the chitosamine-galactose-sulfuric acid-complex in the same glycoprotein could not. Funis mucin-protein was thrown down from water by the aid of formaldehyde at the same $\mathrm{pH}$ adjusted to with $\mathrm{Ba}(\mathrm{OH})_{2}$. In the precipitates was detected no carbohydrate (consult Table I). Limacoitinsulfuric acid ${ }^{35)}$ and heparin ${ }^{45)}$ can be also readily separated from their glycoprotein by a process like the above, leaving the non-hexuronic acidcontaining polysaccharide behind together with the amino acid-grouping.

These and additional experiments led us to believe that hexuronic acid-containing plysaccharides are present to play the rôle of an anion in natural glycoproteins as a salt. Other carbohydrates constructing a socalled glycoprotein could not be split off by gentle means as applied above in so far as examined, and accordingly it might be plausibly assumed that these are combined with the amino acid-grouping in a firm chemical way through principal valencies. It is not meant hereby that all non-hexuronic acid-containing polyoses (hexosamine-containing) are present in a bound 
state in animal body (consult Yasuoka ${ }^{46)}$, Sibuya ${ }^{47}$, and Tiba ${ }^{48) 49)}$ ).

It is naturally considered that the proteins, with which the hexuronic * acid-containing carbohydrates conjugate in tissue, are not restricted to those separable as a constituent of glycoproteins. Based on such a view and on the equivalent proportions found in tissues between protein basic- $N$ and this sort of carbohydrate, we ${ }^{50)}$ could explain why Sasaki had been able to extract a mucoid free from chondroitinsulfuric acid from bull tendon and further indicated that chondroitinsulfuric acid exists mostly, to say the least of it, as free acid in some kinds of cartilage.

\section{Proposal of Dividing Natural So-called Glycoproteins into "Glycid.amins" as Simple Proteins and "Glycoproteins" as Conjugated Proteins.}

The salt naturef of those so-called glycoproteins involving a hexuronic acid-containing polysaccharide justifies them to be real glycoproteins, i.e, conjugated proteins similarly as are nucleo- and chromo-proteins. It does not matter here whether the constituting simple protein is basic or acid. Conjugated proteins may be supposed as mere artificial products, because, in cells and tissues, the prosthetic groups are possibly joined with proteins other than the accompanying when isolated and may be also present in part in a free state, but, nevertheless, their class among proteins will be worth of keeping, since they are separated always as substances involving a specific protein or specific proteins in the molecule.

Coagulable proteins of serum, milk and bird eggs, phosphoproteins ${ }^{51) 52}$ and plant simple proteins, all of which are simple proteins, have been demonstrated to have a carbohydrate composed of hexosamine and hexose, though small in amount, and these carbohydrates are also not detached by treatment with a chloroform-amylalcohol mixture and other like mild agents. From these acid simple proteins, viewed thus, differ not only such so-called glycoproteins as ovomucoid and the mucin from snail foot but also the ones, which associate an itin or an itinsulfuric acid or heparin as in chondromucoid, saliva mucin and so on, only quantitatively but not qualitatively. Not all simple proteins have a carbohydrate, but, because of being chemically bound of the carbohydrate with the amino acid-grouping, carbohydrate-rich proteins as exemplified might be also more legitimately classed in the group of simple proteins as are phosphoproteins by English authors. We name them "glycidamins," In one glycidamin is found only one polysaccharide.

Real glycoproteins contain usually a glycidamin as the constituting protein. Exceptions are those obtainable from umbilical cords and vitreus humor, whose protein component gives amino acids alone on hydrolysis, 
and sclera mucoid $\beta$, in which the simple protein possesses no marked quantity of carbohydrate. Saliva mucin and sclera mucoid $\alpha$ are complicated and made up of a glycidamin, a protein with a minute quantity of carbohydrate and a glucuronic acid-containing polysaccharide. Glycidamins are also separated together with nucleic acid in the form of nucleoprotein. ${ }^{53)}$

\section{Notes.}

* Glucosamine- $\mathrm{N}$ in heparin is not acetylated but sulfurylated.

† Submaxillary mucin owes the present divergency to submaxillary mucoid involved as a component (cf. Hasegawa ${ }^{40)}$ as well as $\mathrm{Oh}-\mathrm{Uti}^{411}$ ).

$\ddagger$ That loose co-ordination helps the conjugation is possible.

\section{Bibliography.}

1) Hamasato and Akakura, J. Bioch., 1941, 34, 159.

2) Yasuoka, Tohoku J. Exp. Med., 1944, 46, 260.

3) Masamune and Tanabe, J. Bioch., 1938, 28, 19.

4) Tanabe, J. Bioch., 1938, 27, 251.

5) Osaki, Tohoku J. Exp. Med., 1947, 49, 15.

6) Masamune, Suzuki, M., and Kondoh, J. Bioch., 1940, 31, 347.

7) Hisamura, J. Bioch., 1937, 26, 359.

8) Suzuki, M. J. Bioch., 1938, 27, 367.

9) Suzuki, H., J. Bioch., 1941, 33, 377.

10) Kobayasi, Tadasi, J. Bioch., 1989, 30, 451.

11) Yasuoka and Sasaki, Tohoku J. Exp. Med., 1947, 49, 5.

12) Suzuki, M., J. Bioch., 1939, 30, 185.

13) Sasaki, Tohoku J. Exp. Med., 1945, 48, 307.

14) Suzuki, H., J. Bioch., 1941, 33, 219.

15) Onoe, J. Bioch., 1936, 24, 1.

16) Osaki and Yosizawa, Tohoku J. Exp. Med., in press.

17) Suzuki, H., J. Bioch., 1944, 36, 395.

18) Suzuki, H., J. Bioch., 1941, 34, 167.

19) Turumi and Sasaki, Tohoku J. Exp. Med., 1947, 49, 1.

20) Hiyama, Tohoku J. Exp. Med., in press.

21) Hiyama, Tohoku J. Exp. Med., in press.

22) Suzuki, M., J. Bioch., 1939, 30, 19.

23) Osaki and Hasegawa, Tohoku J. Exp. Med., 1943, 45, 176.

24) Masamune and Yasuoka, Tohoku J. Exp. Med., 1947, 49, 181.

25) Suzuki, M., J. Bioch., 1939, 30, 193.

26) Tanabe, J. Bioch., 1939, 30, 11.

27) Tanabe, J. Bioch., 1939, 30, 181.

28) Tanabe, J. Bioch., 1938, 28, 227.

29) Tanabe, J. Bioch., 1939, 29, 377.

30) Tanabe, J. Bioch., 1939, 29, 381.

31) Osaki, Tohoku J. Exp. Med., 1947, 49, 19. 
32) Hisamura, J. Bioch., 1938, 28, 217.

33) Hiyama, Tohoku J. Exp. Med., in press.

34) Hisamura, J. Bioch., 1938, 28, 473.

35) Masamune, Yasuoka, Tahahasi and Asagi. Tohoku J. Exp. Med., 1947, 49, 177.

36) Hiyama, Tohoku J. Exp. Med., in press.

37) Osaki and Turumi, Tohoku J. Exp. Med., 1947, 49, 11.

38) Hiyama, Tohoku J. Exp. Med., in press.

39) Takahasi and Yasuoka, Tohoku J. Exp. Med., in press.

40) Hasegawa, Tohoku J. Exp. Med., 1943, 46, 95.

41) Oh-Uti, T., Tohoku J. Exp. Med., 1948, 49, 193.

42) Oh-Uti, T., Tohoku J. Exp. Med., 1948, 49, 207.

43) Asagi, Tohoku J. Exp. Med., this volume, p. 95.

44) Masamune and Yasuoka, Tohoku J. Exp. Med., 1947, 49, 181.

45) Utusi, Tohoku J. Exp. Med., in press.

46) Yasuoka, Tohoku J. Exp. Med., 1948, 49, 213.

47) Sibuya, Tohoku J. Exp. Med., in press.

48) Tiba, Tohoku J. Exp. Med, in press.

49) Tiba, Tohoku J. Exp. Med., in press.

50) Oh-Uti, T, and Utusi, Tohoku J. Exp. Med., 1947, 49, 189.

51) Satoh, Hamasato, Tetu Kobayasi and Sinokawa, Tohoku J. Exp. Med., 1943, 46, 189.

52) Haneda, Sinokawa and Yasuoka, Tohoku J. Exp. Med., 1944, 46, 263.

53) Utusi, Tohoku J. Exp. Med., in prèss. 